\title{
Incidence, Treatment and Visual Outcomes of Non-Infectious Keratitis as a Postoperative Complication of Laser-Assisted in-Situ Keratomileusis (LASIK).
}

\author{
Mahmoud M Saleh, MD; Ahmed I Galhoom,MD; Abdallah E Shelil,MD ; Hasan \\ M Hegazi,MD; and Mohamed A Wahdan,MD. \\ Department of ophthalmology, Faculty of medicine Al Azhar University.
}

\begin{abstract}
Purpose: To study the incidence, treatment, and visual outcomes of Non-Infectious Keratitis as a Postoperative Complication of Laser in-Situ Keratomileusis (LASIK) at Elite Medical \& Surgical Center. K S A

Methods: The files of 3500 post-LASIK patients (6326 eyes) were reviewed for the development of Non-Infectious Keratitis. Incidence, management regimens, and final best spectacle corrected visual acuity (BSCVA) were reported.

Results: Post-LASIK Non-Infectious Keratitis was diagnosed in 149 eyes (2.35\%). The Keratitis was classified as diffuse lamellar keratitis (DLK) in 89 eyes (1.4\%) and 60 eyes $(0.94 \%)$ as localized debris-related Keratitis (LDK).

Conclusion: The occurrence of post-LASIK Non-Infectious Keratitis was 2.35\%, with DLK being the common diagnosis overall, with $92.6 \%$ of patients achieving $\leq 20 / 20$ BSCVA. The best way for prevention of DLK is to eliminate defined predisposing factors for DLK. Close follow-up during the early postoperative period.
\end{abstract}

\section{Introduction:}

Non-Infectious Keratitis can occur shortly after LASIK and lead to irreversible visual loss in severe cases. It is a non-infectious inflammatory reaction in the flap-corneal bed interface which usually occurs one week after LASIK. Other names given to this syndrome include Sterile interface inflammation has been referred to as "sands of the Sahara,"1 diffuse lamellar keratitis (DLK),2 or, perhaps most appropriately, diffuse interface keratitis (DIK). But the term DLK appears more appropriate and is more commonly used.3

DLK has been reported by excimer laser centers all over the world, however the exact etiology still remains unknown.4,5 but seems to be multifactorial.6 Contributing factors include meibomian gland secretions, povidone-iodine, talc powder from surgical gloves, remnants of antiseptics used for cleaning surgical instruments, remnants of bacteria, endotoxins and exotoxins on surgical instruments, balanced salt solution (BSS), epithelial cells and red blood cells beneath the flap, polluted autoclave reservoirs and contaminations and deposits on the microkeratome.7

DLK can range from asymptomatic interface haze near the edge of the flap to marked diffuse haze with diminished best corrected vision. Such inflammation generally resolves by its own without sequelae but severe cases can lead to scarring or flap melting. 
Therefore, many surgeons treat the inflammation with aggressive topical steroids or, in severe cases, irrigation of the interface with antibiotics and steroids. 8

Preventive measures against DLK have not been successful. The role of topical and systemic steroids in the treatment of DLK and prevention of its progression have been studied.9 In one study, topical steroids were used after lifting the flap and before laser application which seemed to decrease the risk of DLK.14 The role of lid scrubbing and treatment of blepharitis prior to LASIK as well as use of systemic steroids and antihistamines in atopic individuals has already been established.10

The clinician must differentiate sterile interface inflammation from potentially devastating infectious inflammation. Infection within the interface can lead to flap melting, severe irregular astigmatism, and corneal scarring that could require penetrating Keratoplasty. If infection is suspected, the flap should be lifted and the interface cultured and irrigated with antibiotics.11

\section{Patients and Methods:}

The files of 3500 patients (6326 eyes) that had LASIK between September 2007 and September 2009 in private LASIK centers. Were reviewed for the development of Non-Infectious Keratitis. They were divided into type I DLK (diffuse or center involved) or type II LDK (localized or center sparing). Clinical characteristics of infiltrates in both types of non infectious keratitis as the following.

\begin{tabular}{|c|c|}
\hline $\begin{array}{l}\text { DLK infiltrates } \\
\text { have the following characteristics }\end{array}$ & $\begin{array}{l}\text { LDK infiltrates } \\
\text { have the following characteristics }\end{array}$ \\
\hline $\begin{array}{l}\text { 1. They are confined to the interface, extending } \\
\text { neither anteriorly into the flap nor posteriorly into } \\
\text { the stroma. } \\
\text { 2. They are diffuse and scattered through a large } \\
\text { area. } \\
\text { 3. There are multiple faint foci. } \\
\text { 4. The infiltrates may be more concentrated around } \\
\text { surgical debris. } \\
\text { 5. There is little or no anterior chamber reaction. } \\
\text { 6. There is no overlying epithelial defect. } \\
\text { 7. The conjunctiva is relatively non-inflamed. }\end{array}$ & $\begin{array}{l}\text { 1. They are located sub-epithelially and do not } \\
\text { extend posteriorly. } \\
\text { 2. They are relatively small in size. } \\
\text { 3. There are multiple foci of infiltrates. } \\
\text { 4. The infiltrates are located in the peripheral part } \\
\text { of the } \\
\text { cornea. } \\
\text { 5. There is little or no anterior chamber reaction. } \\
\text { 6. There is no overlying epithelial defect. } \\
\text { 7. The conjunctiva is relatively non-inflamed. }\end{array}$ \\
\hline
\end{tabular}

All patients had a complete preoperative examination including manifest and cycloplegic refractions, corneal topography, pachymetry, slit lamp and dilated fundus examination.

Incidence, management regimens, and final best spectacle corrected visual acuity (BSCVA) were reported. Diagnosis and staging of DLK were conducted according to the Linebarger, Hardten and Lindstrom criteria as the following:

Grade 1: white granular cells seen in the peripheral cornea with no involvement of the visual axis.

Grade 2: Grade 1 plus involvement of the visual axis. 


\section{Assessment of}

Grade 3: clumping of cells at the visual axis, such that there is reduced vision and haze.

Grade 4: central stromal necrosis and corneal melt, with induced hyperopia and corneal astigmatism.

All LASIK procedures were performed under topical anesthesia With $0.5 \%$ tetracaine. The Moria LSK CarriasoBarraquer microkeratome with a fixed plate was used to cut a flap of 160 micron thickness. Each microkeratome blade was used once for each patient(i.e., for both eyes in bilateral cases) after cleaning by distilled water and wet spears and checking for any deposit or irregularities under the surgical microscope immediately before surgery. After creation of the flap and making sure of its normalcy and central position, laser ablation was performed using the visx star s4 112 excimer laser machine. The flap was then returned to its position and the undersurface was irrigated with a small amount of BSS until there was no visible debris or foreign particles. After performing LASIK on the first eye, if there was no complication and the patient agreed, the procedure was performed in the fellow eye in bilateral cases.

\section{Postoperative treatment}

Postoperative treatment included the use of FML and Oflox drops 4 times a day for 7 days. All patients were reexamined 1 and 7 days and 1 month postoperatively unless complications required more frequent visits.

\section{Results:}

The early sings of diffuse lamellar keratitis (DLK) are evident on the first postoperative day. In some cases, however, while opaque areas appear in the interface by 3 to 5 days. The mean time to diagnosis was not statistically significantly different between DLK (1.8 days) and LDK (1.5 days). The mean time for resolution was 3.4 days in LDK This was significantly shorter than DLK, in which a mean time for resolution was 11.9 days.

Table 1.

\begin{tabular}{|c|c|c|c|c|c|c|c|c|c|}
\hline \multirow{3}{*}{$\begin{array}{c} \\
\text { NON } \\
\text { INFECTIOUS } \\
\text { KERATITIS }\end{array}$} & \multicolumn{9}{|c|}{$\begin{array}{l}\text { Table1.Non infectious keratitis } \\
\text { Incidence, postoperative presentation, days to resolution grading and treatment }\end{array}$} \\
\hline & \multirow[b]{2}{*}{$* \mathrm{IN}$} & \multirow[b]{2}{*}{$\begin{array}{c}\text { POSTOP } \\
\text { PRESENTATION } \\
\text { (D) }\end{array}$} & \multirow[b]{2}{*}{$\begin{array}{l}\text { DAYS TO } \\
\text { RESOLUSTION }\end{array}$} & \multicolumn{4}{|c|}{ GRADES } & \multicolumn{2}{|c|}{ TREATMENT } \\
\hline & & & & 1 & 2 & 3 & 4 & $* \mathrm{FL}$ & $* \mathrm{CORT}$ \\
\hline *DLK & 89 & $1-6$ & $6-45$ & 58 & 22 & 9 & - & 2 & 10 \\
\hline *LDK & 60 & $3-7$ & 4-35 & -- & -- & -- & -- & -- & -- \\
\hline \multicolumn{10}{|c|}{ *DLK=Diffuse lamellar keratitis } \\
\hline
\end{tabular}

Post-LASIK Non-Infectious Keratitis was diagnosed in 149 eyes (2.35\%) Fig1. The Keratitis were classified as diffuse lamellar keratitis (DLK), 89 eyes (1.4\%) and 60 eyes $(0.94 \%)$ as localized debris-related Keratitis (LDK) Fig 2. 

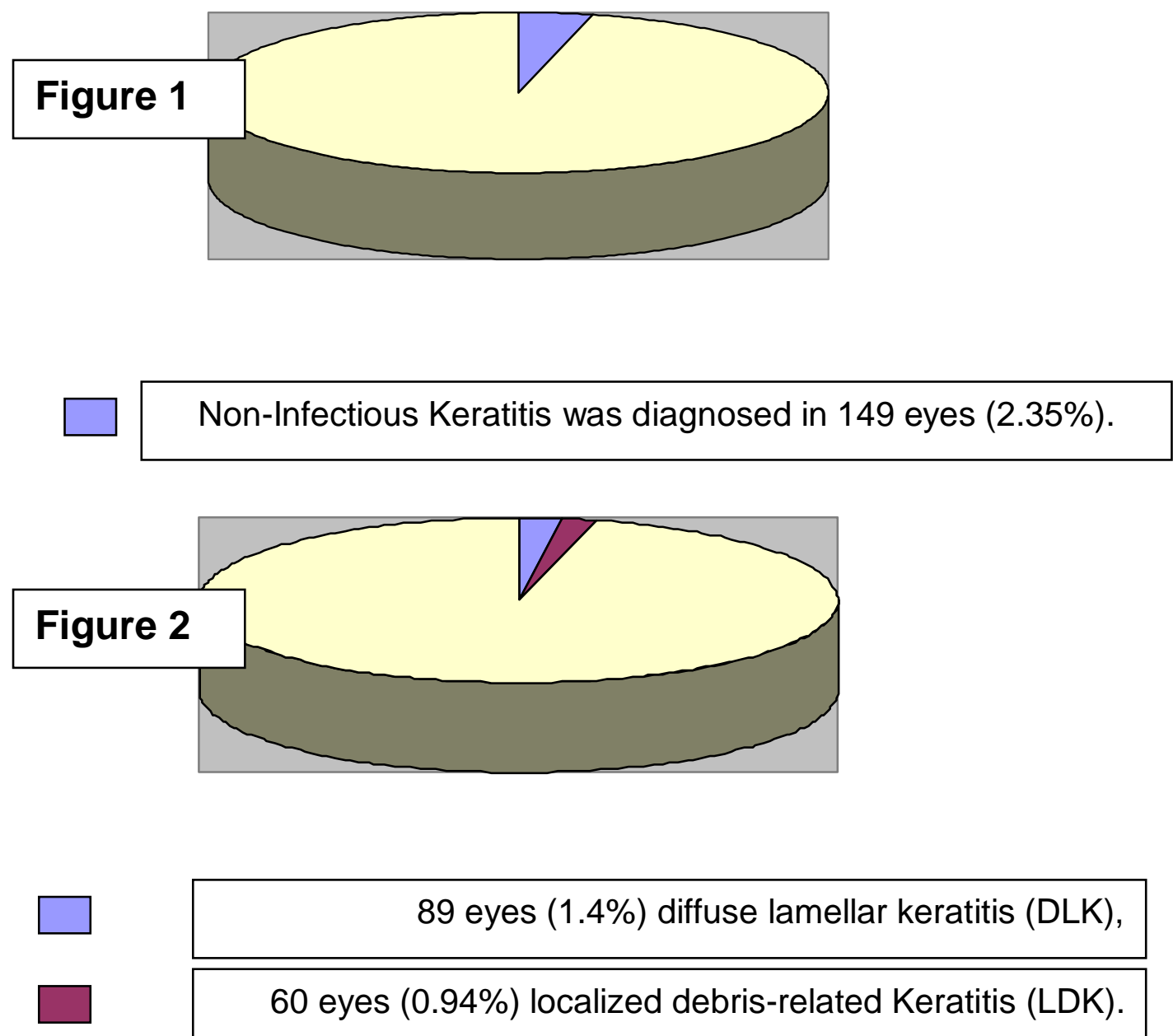

89 eyes $(1.4 \%)$ diffuse lamellar keratitis (DLK),

60 eyes $(0.94 \%)$ localized debris-related Keratitis (LDK).

Visual outcomes

After resolution of keratitis, BSCVA was recorded overall, 138 (92.6\%) of the 149 patients achieved a final BSCVA of $\leq 20 / 20$ and $11(7.38 \%)$ patients achieved a final BSCVA of $\leq 20 / 40$. Table 2 shows Final visual outcomes in both type of Non infectious keratitis

\begin{tabular}{|c|c|c|c|}
\hline \multicolumn{3}{|c|}{ Table 2. Final visual outcomes } \\
\hline \multirow{2}{|c|}{$\begin{array}{c}\text { Non infectious } \\
\text { keratitis }\end{array}$} & $\mathrm{N}$ & $\leq 20 / 20$ & $\leq 20 / 40$ \\
\cline { 3 - 4 } & 89 & eyes $89.88 \% 80$ & eyes $10.11 \% 9$ \\
\hline DLK & 60 & eyes $96.66 \% 58$ & eyes $3.33 \% 2$ \\
\hline LDK & & &
\end{tabular}




\section{Discussion:}

LASIK is now considered the most common refractive procedure. The rate of post-LASIK DLK is usually a mild and transient condition but in severe cases may cause corneal scarring, irregular astigmatism and decreased vision. Corneal infiltrations after LASIK are relatively uncommon complications. Because corneal infiltrates represent a nonspecific accumulation of inflammatory cells, several possible causes should be considered. Probably the most important complication is infectious keratitis. An infection after LASIK can be rapidly progressive and potentially vision threatening. If an infection has been ruled out, other etiologies can be entertained. 12

\section{Figure 3}

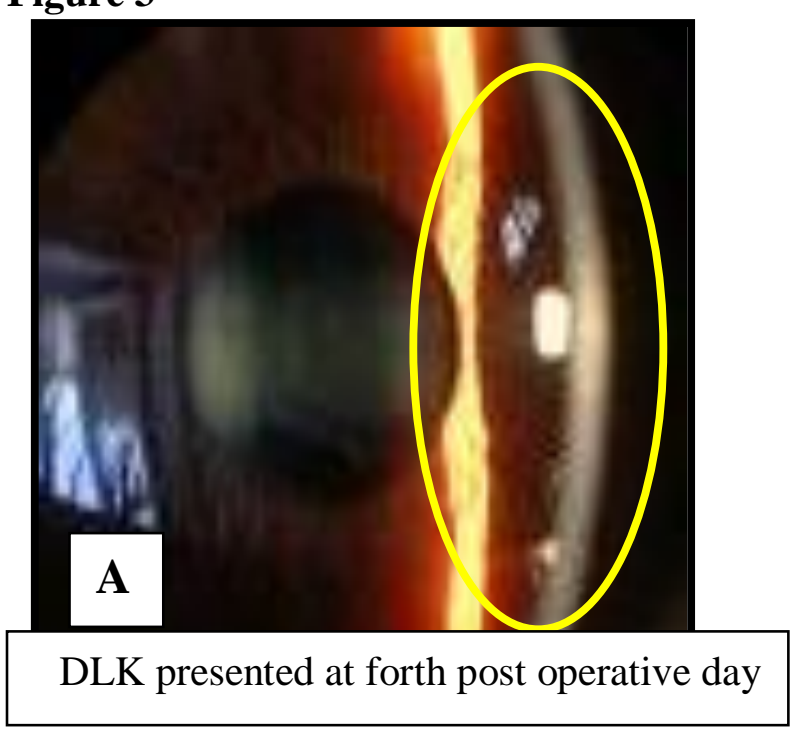

Many previous studies of postLASIK keratitis have focused on infectious etiologies or a specific noninfectious etiology, such as DLK.14 This study focused on noninfectious post-LASIK keratitis, reporting incidence of occurrence, treatment, and visual outcomes.

The incidence of non infectious keratitis in this study was $(2.35 \%)$ and represents 149 eyes with DLK being the common diagnosis which represents (1.4\%) 89 eyes Fig 3. Localized debrisrelated keratitis was noted in 60 eyes Fig 4 and all cases resolved spontaneously within 5 weeks and achieved final BSCVA of 20/40 or better. Surprisingly, $96.66 \%$ achieved BSCVA of 20/20, compared with $89.88 \%$ of DLK cases

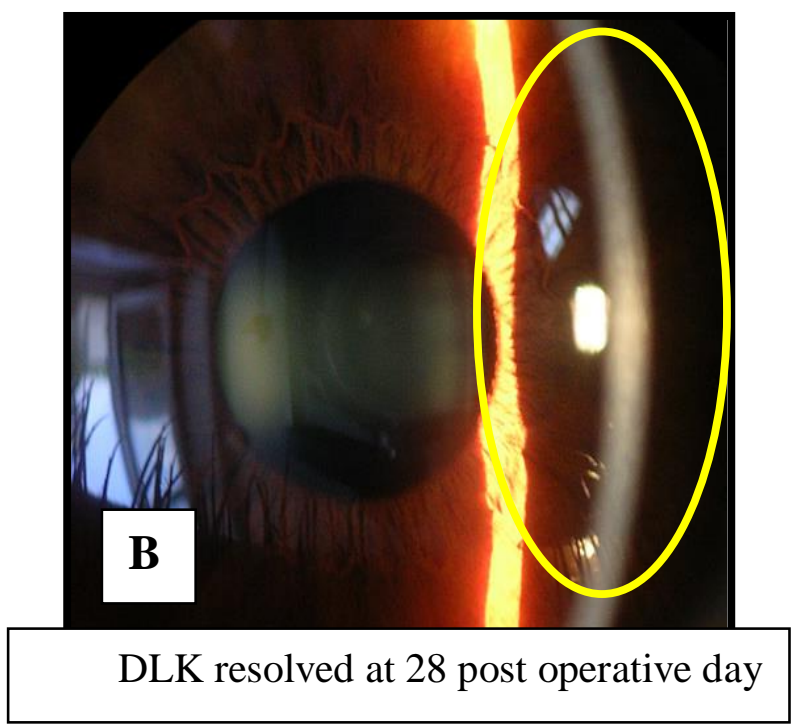




\section{Figure 4}
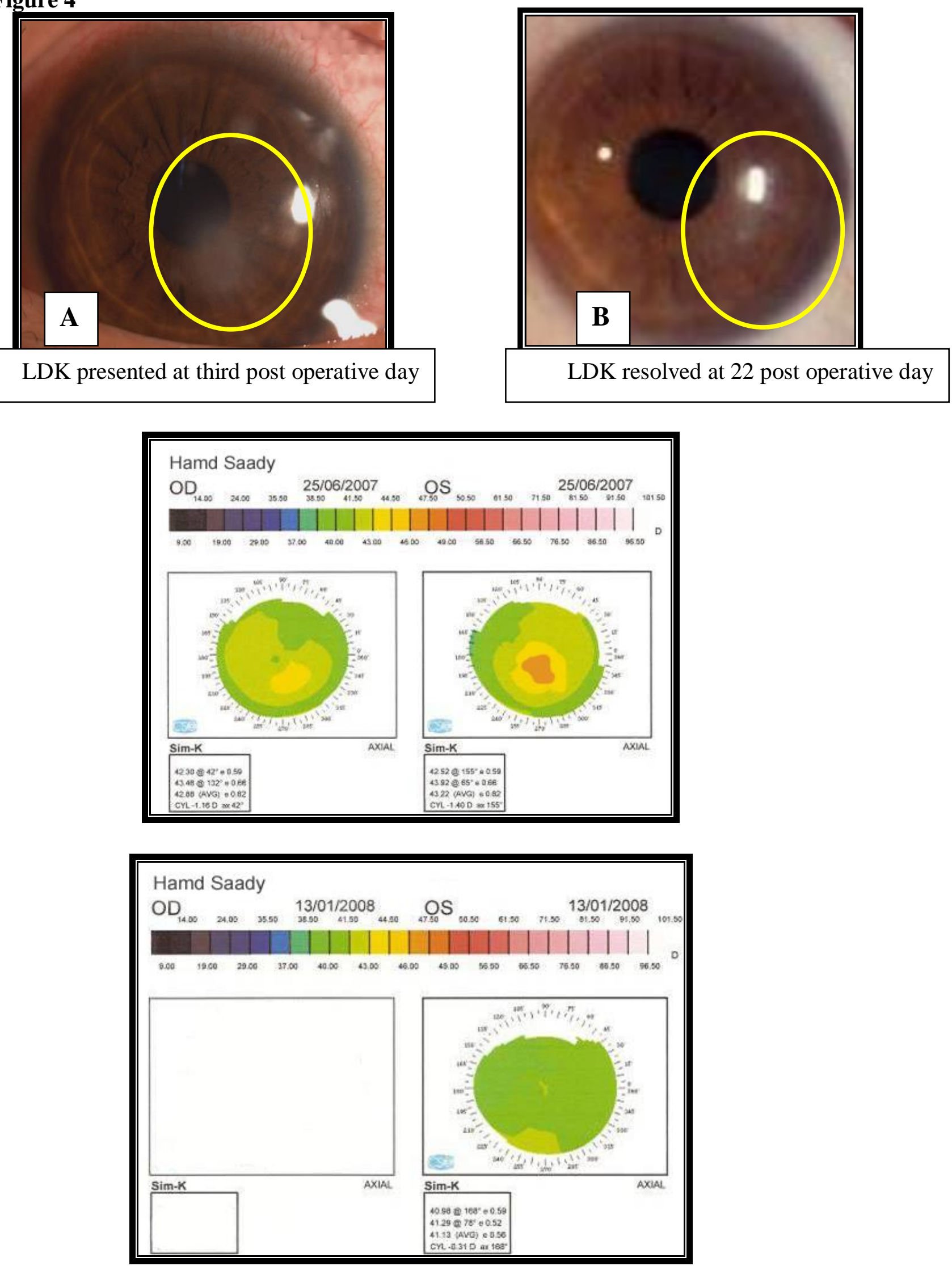

Figure 5. Corneal topography evolution in the left eye shows a progressive reduction of the central corneal flattening. Left: At 6 days post op. right: At 6 month. 
No patient in this study developed permanent loss of corneal clarity, and none lost BSCVA. Two eyes were treated with interface irrigation, with excellent outcomes. Ten eyes with stage 3 DLK were treated with combination of high-dose oral and topical steroids (oral Prednisolone 1 to $1.5 \mathrm{mg} / \mathrm{kg} /$ day, then systemic steroid was discontinued over 7-10 days after control of DLK). To eliminate serious ocular morbidity and the occurrence of stage 4.all were fully recovered without loss of BSCVA or a hyperopic deviation.

Richard et al ( 2004) studied 1000 eyes, diffuse lamellar keratitis developed in 40 eyes (4\%)13 the incidence was higher than this study but In other study Majid et al (2007) on 10477eyes the rate of post lasik infectious and non infectious keratitis was $2.66 \%, 2.34 \%$ respectively. 14

The principal treatment for DLK is the use of topical steroids, usually potent preparations such as prednisolone acetate $1 \%$. Other steroids can also be effective and we changed to other formulation after having a rise in intraocular pressure due to the steroid. Such a rise is more likely with the use of more potent agents. Consideration of intraocular pressure in patients receiving high-dose topical steroids is important, especially in LASIK patients. Applanation and Tono-Pen tonometry underestimate intraocular pressure on thinner post-LASIK corneas. In addition, an acute rise in pressure can cause fluid from the anterior chamber to accumulate in the cornea at the LASIK interface. This may be mistaken for an increase in inflammation due to DLK and may lead to a further underestimation of the pressure. Patients who have been maintained on steroids may develop undetected marked elevation of intraocular pressure and lose of substantial vision secondary to glaucomatous optic neuropathy.15 Therefore, careful monitoring of intraocular pressure during treatment with steroids is essential. Comparison of IOP with pretreatment levels will help with detecting steroid responders. The patient in this report was a steroid responder and the resultant ocular hypertension was treated with timolol.16

\section{Conclusion:}

The occurrence of post-LASIK NonInfectious Keratitis was 2.35\%, with DLK being the common diagnosis overall, with most of patients achieving $\leq 20 / 20$ BSCVA. The best way for prevention of DLK is to eliminate defined predisposing factors for DLK. Close follow-up during the early postoperative period for early diagnosis and treatment of this potentially sight threatening complication may prevent permanent corneal damage.

\section{References:}

1. Kaufman SC, Maitchouk DY, Chiou AGY et al: Interface inflammation after laser in situ keratomileusis. Sands of the Sahara syndrome. J Cataract Refract Surg 24:1589, 1998

2.Smith RJ, Maloney RK: Diffuse lamellar keratitis. A new syndrome in lamellar refractive surgery. Ophthalmology 105:1721, 1998

\section{Steinert RF, McColgin AZ, White A et al:} Diffuse interface keratitis after LASIK: A nonspecific syndrome. Am J Ophthalmol 129:380, 2000

4. Buratto L, Brint S. Complications of LASIK. In: Buratto L, Brint S. LASIK: surgical techniques and complications. Thorofare NJ: Slack Inc.; 1999: 239-243.

5. Johnson JD, Harissi-Dagher M, Pineda R, Yoo S, Azar DT. Diffuse lamellar keratitis: incidence, associations, outcomes and a new classification system. J Cataract Refract Surg 2001; 27:1560-1566

\section{Iskander NG, Peters NT, Anderson Penno} EE, Gimbel HV. Postoperative complications in LASIK. Curr Opin Ophthalmol 2000; 11:273279.

7. Holland SP, Mathias RG, Morck DW, Chin J, Slade SG. Diffuse lamellar keratitis related to endotoxins released from sterilizer reservoir biofilms. Ophthalmology 2000;107:1227-1233. 
8. Macrae SM, Rich LF, Macaluso DC. Treatment of interface keratitis with oral corticosteroids. J Cataract Refract Surg 2002;28:454-461.

9. Peters NT, Lingua RW, Kim CH. Topical intrastromal steroid during laser in situ keratomileusis to retard interface inflammation. J Cataract Refract Surg 1999; 25:1437-1440

10. Boorstein SM, Henks HJ, Elner VM.

Atopy: a patient-specific risk factor for diffuse lamellar keratitis. Ophthalmology 2003; 110:131:137.

\section{Linebarger EJ, Hardten DR, Lindstrom}

RL. Diffuse lamellar keratitis: diagnosis and treatment. J Cataract Refract Surg 2000; 26:1072-1077

12. Stulting RD, Randleman JB, Couser JM, Thopson KP. The epidemiology of diffuse lamellar keratitis. Cornea 2004; 23:680-688.
13.Richard S. Hoffman, MD, I. Howard Fine, MD, Mark Packer, MD Incidence and outcomes of LASIK with diffuse lamellar keratitis treated with topical and oral corticosteroids J Cataract Refract Surg2003;29:451-456.

14.Majid M,John DW, Vahid F, Huck H,Thomas EC.Infectious and noninfectious keratitis after laser in situ keratomileusis occurrence, management, and visual out com J Cataract Refract Surg 2007;33:474-483.

15.Majmudar P. A new masquerade syndrome following LASIK. J Cat Refract Surg Today2003; Feb: 28.

16. Ambrósio Jnr R, Wilson SE.

Complications of laser in situ keratomileusisaetiology,

prevention and treatment. J Cat Refract Surg2001; 17: 350-379. 


\section{معدل حدوث التهاب القزنية الغير ميكروبي كمضاعفه لعملية الليزك

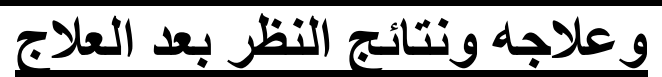

محمود محمد صالح و أحمد ابراهيم جلهوم وعبد الله الحسينى شليل وحسن محمد حجازى و محمد أحمد وهدان قسم الرمد التئي

كلية الطب الرمب

جامعة الازهر الطب

يقوم هذا البحث على دراسة معدل حدوث التهاب القرنية غير المعدي كأحد مضاعفات عملية الليزتك والتي تؤدى إلى إعتام القزنية وتدهور الإبصار في الحالات المهملة والثديدة. وقد تم مراجعة ملفات المرضى(3500)ملف بعد عمليات الليزك(6326) وجد أن معدل الاصابه

$$
\text { يمثل)(2.35\%). }
$$

وتم تقسيمهم إلى 89 حاله التهاب طبقي شامل بالقرنية و60 حاله التهاب محدود بالقرنية.

و تم تثخيص هذه الحالات وعلاجهم بمضادات الالتهاب( الاسترويد) و كانت نسبة/التحسن \% 92.6 من الحالات المصابة وتحسنت قوة الإبصار إلى تصن 20/20. 